\title{
Socialization on the Importance of Saving for the Young Generation to Students at Baiturrahman Elementary School Tasikmalaya City
}

\author{
Grida Saktian Laksito \\ Research Colaboratory Community, Bandung, Indonesia \\ *Corresponding author email: gridasaktianlaksito@gmail.com
}

\begin{abstract}
The socialization of the love of saving is a form of community service, with the aim of helping elementary school students to increase their understanding of the importance of saving from an early age to SD Baiturrahman Tasikmalaya City. Saving in various perspectives is highly recommended because the habit of living extravagantly will only leave difficulties in the future, in accordance with the motto of saving money on a rich base. This method of community service activity begins with the preparation stage and field survey. This survey stage begins with direct discussions with the Principal of SD Baiturrahman Tasikmalaya City to identify student behavior in managing finances given by their parents as provisions at school, after knowing the behavior of students in managing their finances, the next activity will be carried out face to face using the method of delivering socialization materials with counseling techniques, questions and answers, quizzes, creations to make piggy banks, as well as by adding games. The results of this study are to provide knowledge of participants who are SD Baiturrahman Tasikmalaya City, where previously they were less enthusiastic in saving and getting used to living extravagantly. After participating in the socialization activity for liking to save, students are able to distinguish between necessities and wants, learn how to treat the two items and can apply saving behavior from an early age.
\end{abstract}

Keywords: Sociaziation, Savings Movemen, Early Age

\section{Introduction}

The saving culture of the Indonesian people is quite low when compared to other Asian countries. This fact is reflected in the low marginal propensity to save or the desire to save people, even though gross domestic product (GDP) increases. The Central Statistics Agency (BPS) noted that in 2015 the ratio of savings to GDP was only 34.8\%. This figure is still lower than Singapore and China which reached $49 \%$ or the Philippines at $46 \%$. In fact, Indonesia has a very large population. This amount should be one of the strengths for the national financial services industry in increasing the saving portion ratio ( Surani et al., 2021a; Drever et al., 2015)

Responding to this phenomenon, the Financial Services Authority (OJK) as a regulator has initiated a national program in the form of Student Savings savings. The aim of the program is to build and shape a 
culture of saving from an early age. For the state, saving can reduce state debt by increasing national investment, while the benefits for individuals are benefiting from the principle of interest, profit sharing and so on (Isomidinova et al., 2017; Maryuhina, 2021).

It is very important for young people to improve their financial well-being, this can be achieved through enhanced financial socialization (LeBaron et al., 2018; Shim et al., 2015). This time is very timely given the current financial crisis with the restrictions related to COVID-19, as previous research has shown that the majority of young people who are financially vulnerable are often severely affected by financial disasters (Kim et al., 2017). Moreover, in case of crisis, young people try to reduce spending, and try to better adjust their financial plans, which leads to a slowdown in economic recovery (Mian et al., 2013; Sohn et al., 2012).

The application of financial parenting needs to be applied from an early age, because children are accustomed to managing money from a young age, it will have a positive impact on their financial management as adults. In accordance with research results Amilia et al. (2018) stated that parental socialization has a significant effect on children's saving behavior at an early age, so that the role of parents is the main socialization in the child's learning process about money and the process of developing financial management behavior provided by the family. The younger generation's emphasis on lifestyle actually fits perfectly with the current saving perspective, namely saving is part of a lifestyle, by saving teenagers will benefit from a lifestyle that has been applied at an early age by utilizing the saving system in digital banking.

The habit of saving from an early age provides benefits for children to organize their future, because saving is one of the basics of learning in financial planning, by saving every child will learn to be independent and not depend on their parents. The habit of saving is much better if every child gets encouragement from their parents in terms of reminding them every day so that children want to set aside their pocket money for savings (Webley and Nyhus, 2013; Rea et al., 2019).

One way for parents to teach good saving habits is to introduce students to the function of banks to save money. Parents can invite students to save at the bank so that they understand that when saving at the bank, we will become a customer who has the responsibility to manage their personal finances. So that one day each of these students will have savings that will be useful for their future interests without depending on their parents.

Socialization is one way to influence a person's habits to want to follow something that is expected to be practiced. Likewise, getting used to saving elementary school students can be done with alternative socialization activities directly to them at school. Direct socialization activities to students aim to facilitate the delivery process through two-way interaction between resource persons and participants (Solheim et al., 2011; Austin, 2002).

According to Kim dan Chattarjaee (2013), childhood is a financial socialization experience that is positively associated with beneficial financial practices and financial asset ownership Young adults who have bank accounts and their expenses monitored by parents in childhood are more likely to own financial assets and have a more positive attitude towards finances personally as a young adult.

Based on research conducted by Surani et al. (2021b) mentioned that by socializing the love of saving, children gain knowledge about the benefits and tips as well as knowing how to make piggy banks from simple materials and can regenerate the habit of saving in the next generation of Indonesian youth which in the end is able to contribute to the nation and state.

"The Savings Money Movement for Elementary School Students" is one of the socialization efforts to provide education to students to learn to live independently, both in terms of preparing for their personal needs and other needs. It is hoped that this socialization can increase students' creativity in managing their finances (financial management). Mardiana et al. (2020), stated that there needs to be continuous socialization and motivation in order to increase students' knowledge and interest in saving. The maps location SD Baiturrahman Tasikmalaya City can be seen in Figure 1. 


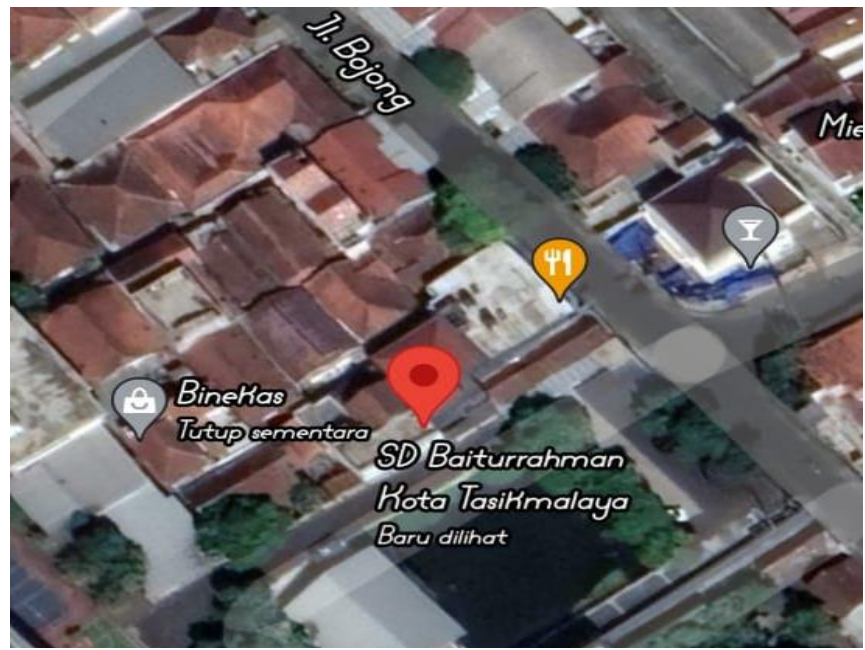

Figure 1 Maps Location SD Baiturrahman Tasikmalaya City

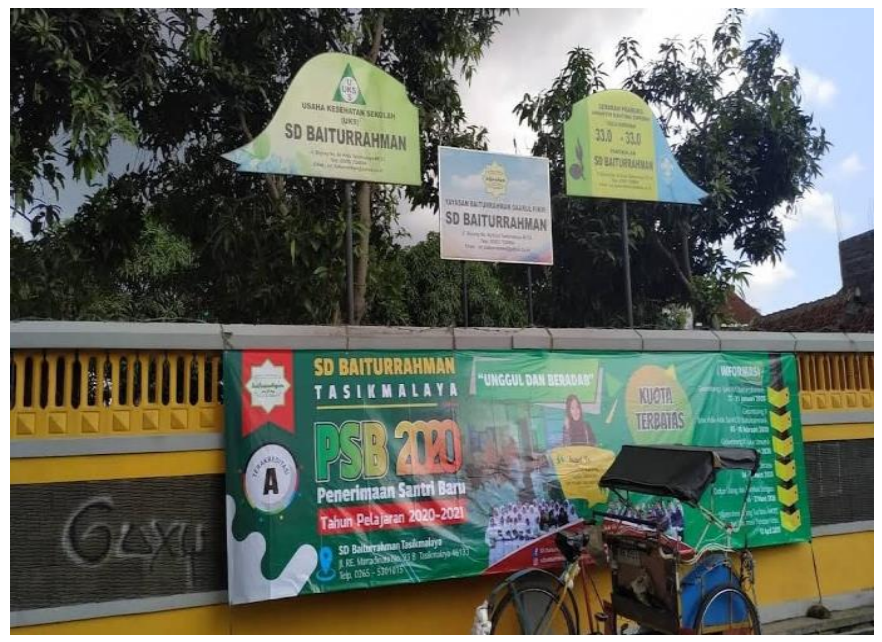

Figure 2 SD Baiturrahman Tasikmalaya City

The purpose of this community service is to help SD Baiturrahman Tasikmalaya City (see Figure 2), in implementing a frugal lifestyle and likes to save. Some of the things the team did in this community service activity were providing socialization of understanding how to save and set aside money provided by their parents, being able to distinguish between necessities and wants, and they were able to save money in a piggy bank or bank so that the future would be brighter.

\section{Materials and Methods}

\subsection{Materials}

The implementation of the service activity will take place on July 28, 2021 at Jl. R.E. Martadinata No.93B, Cipedes, Kec. Cipedes, Kab. Tasikmalaya, Jawa Barat. The target of this PKM program is for early age children or elementary school children as many as 60 people consisting of grades 3 to 6 . The activity is carried out using several stages: Preparation stage; The implementation stage of socialization regarding the financial literacy movement through saving for early childhood; and reporting stage. This activity is carried out face-to-face, starting with observation and coordination and licensing with the local 
school principal regarding the planned activities to be carried out in the environment regarding the availability of places, times, and participants.

\subsection{Methods}

The method used in the implementation of PKM activities is socialization with counseling techniques in the form of lectures or presenting material in the form of theories and animated videos related to saving, questions and answers, creations, and games, including:

- Observation Stage

This activity is carried out as the beginning of the activity with the aim of obtaining a description of the condition of the target community; namely by holding a meeting with the Head of the School SD Baiturrahman Tasikmalaya City with Mr Anasah Qodarudin, S.Pd.I

- Socialization Stage

At this stage, the service team will provide and explain the service plan that will be carried out so that time and various technical needs can be arranged in connection with the overall implementation of the training.

- Extension Implementation Stage

The implementation of community service is carried out in collaboration with the parties SD Baiturrahman Tasikmalaya City. In this counseling, these students will be given an explanation about the importance of saving for the achievement of their goals in the future. Community Service Programs that we carry out in SD Baiturrahman Tasikmalaya City such as: Introducing the culture of saving to students, training in managing their own finances, especially children in the SD Baiturrahman Tasikmalaya City to save from an early age, educating children to be able to calculate how much pocket money and how much money to save, and make a piggy bank that is environmentally friendly and easy to find so that students feel enthusiastic about saving.

\section{Results and Discussion}

Community Service Activities (CSA) are carried out in Jl. R.E. Martadinata No.93B, Cipedes, Kec. Cipedes, Kab. Tasikmalaya, Jawa Barat, which is carried out with the extension method with the aim of providing knowledge or education about the importance of saving from an early age, so that children can learn about how to manage money as early as possible. The implementation of this counseling is fully supported by the school and by giving permission to organize these activities.

We carry out these activities while still carrying out the Covid-19 health protocol recommended by the government, namely by wearing masks, washing hands and maintaining distance. Before starting our activities, we conducted a Covid 19 Health Protocol Check and Participant Registration. This outreach activity began with remarks from the chief executive, followed by the presentation of the material and a question and answer discussion with the participants.

There are 2 resource persons who come from group members who take turns delivering material. The first resource person, Gina Zakiyah, explained the definition of saving, the benefits of saving, and tips for saving. Meanwhile, the second speaker, Kintan Apriawati, explained how to set aside money for saving, and gave examples of creating and decorating savings. In this material, animated video interludes are also provided which can provide additional education to participants to better understand the concept of saving and the existence of games to keep their focus on listening to the material presented and to avoid boredom.

The end of this material is the practice of making and decorating a child's piggy bank made of materials that are around and environmentally friendly, then followed by questions and answers and quizzes. This activity was attended by 60 participants from PAUD and some participants were very 
enthusiastic about asking and answering questions given by the committee, then at the end of the implementation by giving souvenirs and taking pictures with the participants of the socialization.

During service activities there are difficulties or obstacles in their implementation, namely where on the day of implementation many participants cannot attend, this happens because there are still many children who are not allowed to leave the house due to the Covid 19 pandemic. not conducive because participants always talk to their friends and play which causes the focus of other participants on delivering the material to be disturbed, disturbing what is conveyed by the resource person.

\section{Conclussion}

This outreach activity has increased understanding of the importance of saving from an early age so that participants who are students SD Baiturrahman Tasikmalaya City increase interest in saving for the future and increase ability in making children's piggy bank creations.

It is recommended that in the application of Savings for early childhood, parents, teachers and financial institutions such as banks can get used to saving and fully support them. Instilling an interest in saving in children from an early age is expected to be able to regenerate the habit of saving in the next younger generation of Indonesia which will ultimately be able to contribute to the nation and state. We hope that with this service, they can add useful knowledge in terms of introducing the culture of saving from an early age and they will become aware of differentiating between necessities and wants.

\section{References}

Amilia, S., T. P. L. Bulan, and M. Rizal. (2018). Pengaruh Melek Finansial, Sosialisasi Orang Tua, Dan Teman Sebaya Terhadap Perilaku Menabung Mahasiswa Bidik Misi Fakultas Ekonomi Universitas Samudra.Jurnal Samudra Ekonomika 2(2), 97-107.

Austin, A. E. (2002). Preparing the next generation of faculty: Graduate school as socialization to the academic career. The journal of higher education, 73(1), 94-122.

Drever, A. I., Odders-White, E., Kalish, C. W., Else-Quest, N. M., Hoagland, E. M., \& Nelms, E. N. (2015). Foundations of financial well-being: Insights into the role of executive function, financial socialization, and experience-based learning in childhood and youth. Journal of Consumer Affairs, 49(1), 13-38.

Isomidinova, G., Singh, J. S. K., \& Singh, K. (2017). Determinants of financial literacy: a quantitative study among young students in Tashkent, Uzbekistan. Electronic Journal of Business \& Management, 2(1), 61-75.

Kim, J., \& Chatterjee, S. (2013). Childhood Financial Socialization and Young Adults' Financial Management. Journal of Financial Counseling \& Planning, 24(1), 1-12.

Kim, K. T., Wilmarth, M. J., \& Henager, R. (2017). Poverty levels and debt indicators among low-income households before and after the Great Recession. Journal of Financial Counseling and Planning, 28(2), 196212 .

LeBaron, A. B., E. J. Hill, C. M. Rosa, T. J. Spencer, L. D. Marks, and J. T. Powell. (2018). I Wish: Multigenerational Regrets and Reflections on Teaching Children about Money. Journal of Family and Economic Issues 2(39), 30-32.

Mardiana, S., Supriyatna, W., Zakaria, Z., Dumilah, R., \& Budhiarjo, I. S. (2020). Sosialisasi dan Penyuluhan Tentang Pentingnya Menabung Bagi Generasi Muda Khususnya Siswa Madrasah Tsanawiyah Mts Mathlaul Anwar Pamulang. Dedikasi Pkm, 1(2), 79-86. 
Maryuhina, V. (2021). Family Traditions as a Condition for Socialization of Young Generation (Based on a Sample of Tuva Republic). The Family Journal, 10664807211000722.

Mian, A., K. Rao, and A. Sufi. (2013). Household Balance Sheets, Consumption, and the Economic Slump. The Quarterly Journal of Economics 4(128):1687-1726.

Rea, J. K., Danes, S. M., Serido, J., Borden, L. M., \& Shim, S. (2019). "Being able to support yourself”: Young adults' meaning of financial well-being through family financial socialization. Journal of Family and Economic Issues, 40(2), 250-268.

Shim, S., Serido, J., Tang, C., \& Card, N. (2015). Socialization processes and pathways to healthy financial development for emerging young adults. Journal of Applied Developmental Psychology, 38, 29-38.

Sohn, S. H., Joo, S. H., Grable, J. E., Lee, S., \& Kim, M. (2012). Adolescents' financial literacy: The role of financial socialization agents, financial experiences, and money attitudes in shaping financial literacy among South Korean youth. Journal of adolescence, 35(4), 969-980.

Solheim, C. A., Zuiker, V. S., \& Levchenko, P. (2011). Financial socialization family pathways: Reflections from college students' narratives. Family Science Review, 16(2), 97-112.

Surani, D., Prabawati, A. T., \& Fernanda, T. (2021a). Socialization And Counseling Of Saving Movement For The Early Young Generation: Sosialisasi Dan Penyuluhan Gerakan Menabung Sejak Dini Bagi Generasi Muda. Indonesian Journal of Engagement, Community Services, Empowerment and Development, 1(2), 112118.

Surani, Dewi, Anggun Tri Prabawati, and Tantri Fernanda. (2021b). Sosialisasi Dan Penyuluhan Gerakan Menabung Sejak Dini Bagi Generasi Muda. 1(2), 112-18.

Webley, P., \& Nyhus, E. K. (2013). Economic socialization, saving and assets in European young adults. Economics of Education Review, 33, 19-30. 